\title{
Rural and Urban Transitions with Biogas and Biomethane in Brazil: a Water- Energy-Food Nexus Analysis
}

\author{
J.C. Pasqual ${ }^{1,2,3}$, H. A. Bollmann ${ }^{1}$, C. Scott ${ }^{3}$, S. Andersen ${ }^{4}$, M. V. Lange ${ }^{4}$ \\ ${ }^{1}$ Master's and Doctoral Program in Urban Management, Pontifical Catholic University of Paraná, Curitiba, Paraná, 80215- \\ 901, Brazil \\ E-mail: janaina@maxc.com.br; harry.bollmann@pucpr.br \\ ${ }^{2}$ International Center of Renewable Energies - Biogas and International Center of Hydroinformatics, Foz do Iguaçu, \\ Paraná, Brazil \\ ${ }^{3}$ Udall Center for Studies in Public Policy/ School of Geography \& Development, University of Arizona Tucson, Arizona, \\ United States. Email: cascott@email.arizona.edu \\ ${ }^{4}$ Post Graduate Programme in Environment and Development (PPGMADE), Federal University of Paraná, Curitiba, Paraná, \\ Brazil. Email: sigandersen@netpar.com.br; marcelavlange@gmail.com
}

\begin{abstract}
Brazil has historical concerns about renewable sources of energy, mainly because it is the largest tropical country in the world, receiving intense solar radiation, which is the basis of biomass production. In addition, the country has exceptional soil and climate conditions and great biodiversity. Agriculture and livestock activities are very representative in the Brazilian economy and produce usable biomass, which entail renewable sources of energy and the need for residue management. In this context, biogas represents a basic energy source; it is generated via planned treatment of animal, human and industrial wastes. This has two main results: a) the generation of electric, thermal, and vehicular (biomethane) energy; and b) the reduction of greenhouse gas emissions and resultant mitigation of global warming. This paper assesses agricultural biogas projects being developed by Itaipu Binational, the second largest hydroelectric power generation company in the world, which has diversified its energy production from hydropower into other renewable sources such as biogas. In addition to promoting environmental and economic benefits, it promotes local social development, since the process for biogas production constitutes and sustains a relatively complex supply chain, requiring local skilled labor, technical and scientific support, and environmental awareness in the population. We conclude with implications of the Itaipu biogas case example for a range of other contexts.
\end{abstract}

\section{Key words}

Renewable energy, biogas, animal waste, environmental management, power generation.

\section{Introduction}

The interest in energy from renewable sources is increasing due to its environmental benefits. This growing interest is prompting governments, power utility companies and private individuals to evaluate technologies for generating energy from a wide range of renewable sources, which were previously considered economically not viable [1].

Biogas is a renewable and high-quality fuel, currently produced in many developed countries [2]. Despite its advantages and favorable production conditions, biogas energy used in developing countries remains low due to technical, economic and political impediments. Different incentives and barriers, including energy, agricultural, and environmental policies affect biogas systems [3].

This source of renewable energy can be produced from a wide range of raw materials, from organic waste to agricultural and forest residues, and can be used for a lot of energy services such as electric, thermal or vehicular energy (biomethane) [4]. On-farm biogas energy production is a possible source of income for farmers, besides promoting environmental benefits with the liabilities reduction.

The agricultural and livestock productions are representative economic activities in Brazil, and Paraná state is the biggest producer of poultry, the third of dairy, the fifth on swine production and ninth on cattle production [5]. Despite their polluter potential, these activities can, through an efficient management, reduce 
their impacts on the environment and generate profits for producers.

This paper analyzes the benefits of biogas and biomethane for sustainable regional development based on the waterenergy-food nexus in the Brazilian scenario and presents a best practice project placed in Foz do Iguaçu, Parana, which converts wastes from a cattle and poultry production into biomethane vehicular energy.

\section{Objectives}

1) To assess the benefits of biogas and biomethane for sustainable regional development based on the waterenergy nexus-food in the Brazilian scenario;

2) To present a project developed by Itaipu Binational and the International Center of Renewable Energy - Biogás, and its results regarding the use of biogas for vehicular energy (biomethane) and reduction of greenhouse gas emissions;

3) To analyze existing public policies in Brazil for the implementation of biogas and biomethane projects and main challenges.

\section{Water-energy-food nexus global context}

Water, energy and food are the most important resources that humanity has to ensure the sustainability of the planet. They are valuable resources and interdependent, since water is ubiquitous for the production of energy and food and energy is vital for the supply of water required for collection systems, transportation, distribution and handling [6].

According to Scott, Kurian and Wescoat Jr [7], institutional support for the WEF Nexus gained significant momentum via the Bonn Freshwater Conference, the Bonn 2011 Nexus Conference, the Stockholm World Water Week, the United Nations Economic Commission for Europe, and the now well established "Water, Energy, and Food Security Nexus Resource Platform".

Global projections indicate that demand for freshwater, energy and food will increase meaningfully over the next decades under the pressure of population growth and mobility, economic development, international trade, urbanization, diversifying diets, cultural and technological changes, and climate change [8].

According to FAO [9], agriculture demands $70 \%$ of total global freshwater withdrawals, representing the largest user of water. Water is used for agricultural production, forestry and fishery, along the entire agri-food supply chain, and it is used to produce or transport energy in different forms. At the same time, the food production and supply chain consumes about 30 percent of total energy consumed globally [10].

In this context, biogas is a key factor as it is generated through food production, avoids water pollution and can generate different types of energy. The implementation of biogas systems on developing countries can lead to significant improvements concerning resource efficiency and environmental impacts compared to current agricultural production practices. Livestock and, in this case, poultry production generate a large amount of residues that can be used to biogas production and avoid water and air pollution [11].

Biogas is a renewable on-farm produced fuel and its production could be a significant contribution to the fulfilling of national and international policy objectives [12]. However, in spite of the multiple benefits of biogas systems, current Brazilian production is very low and utilizes only minimal part of the country potential [13]. But some incentives and regulations are encouraging the biogas projects. The following section will present Brazilian energy matrix and biogas scenario.

\section{Water-energy-food nexus: the Brazilian scenario}

Brazil is privileged in the availability of water resources, having $12 \%$ of the world's fresh water $\left(180,000 \mathrm{~m}^{3} / \mathrm{s}\right)$. Water availability per person in Brazil is 32,000 $\mathrm{m}^{3} /$ person/year, 19 times higher than the minimum established by the United Nations. In Brazil, $47 \%$ of municipalities are serviced exclusively by surface water, $39 \%$ by groundwater and $14 \%$ by the two types (mixed supply) [14].

Due to the water availability, Brazilian energy matrix is one of the most renewable in the world, composed by $40.4 \%$ of renewable sources, while the world index is $13.2 \%$ and OECD is $8.6 \%$.

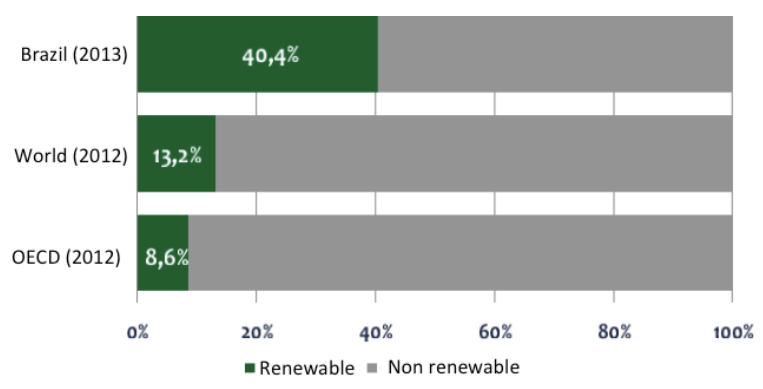

Fig. 1: World, OECD and Brazilian energy matrix Source: Brazilian Energy Research Company, 2015

The electric matrix in Brazil in 2014 was composed primarily of renewable energy sources $(74.6 \%)$, and of this total, $65.2 \%$ corresponded to hydraulic energy, $7.4 \%$ to biomass and $2.0 \%$ to eolic. It is important to highlight that in 2013 the hydraulic energy was more representative $(70.6 \%)$, due to favorable hydrological conditions [15]. 


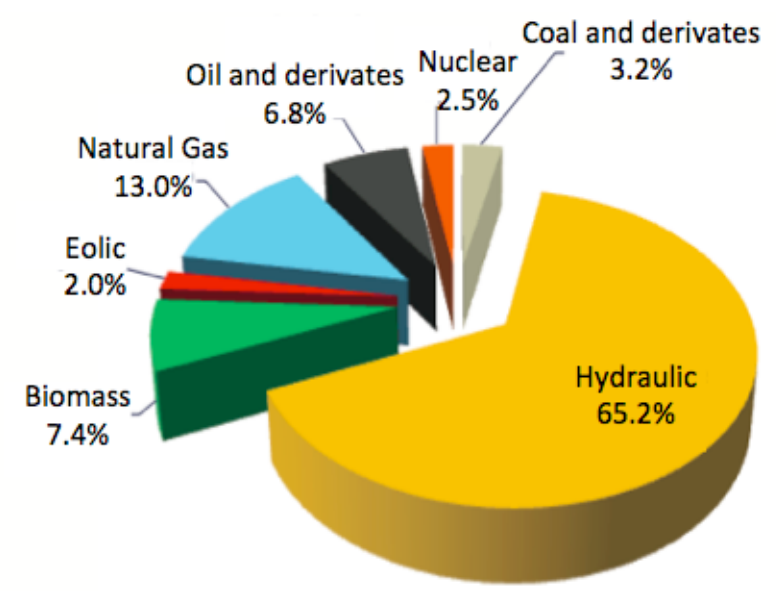

Fig. 2: Brazilian electric matrix in 2014

Source: Brazilian Energy Research Company, 2015

Besides its big biomass potential as renewable source of energy, Brazil occupies the third position in Clean Development Mechanism projects (behind China and India). Making an analysis by sector, the predominance of CDM project activities in Brazil is in the energy sector (51.4\% and 245 projects under development) and swine activity (15.9\% and 76 projects), representing the importance of biomass.

These projects support the growing energy demand in Brazil (due to the economic growth) and improve the electricity supply, contributing at the same time, to the environmental, social and economic sustainability. This is possible through the increased participation of sustainable energy in relation to the total electricity consumption in Brazil, substituting, the construction of power plants using fossil fuels. Studies show that long-term use of biomass energy is more advantageous than employing the land for carbon sink forests [16].

Besides contributing as renewable source of electricity, biogas can also be purified and converted into biomethane, used as vehicular energy. In Brazil, 49.2\% of actual vehicular energy matrix is composed by oil, $32.1 \%$ by gasoline, $14.1 \%$ by ethanol, $2.4 \%$ by biodiesel, and $2.2 \%$ by vehicular natural gas [17]. This indicates that there is a lot of room for renewables energies development.

Brazil is the fifth country on the list of top agricultural producers in the world and this represents a vast biogas potential. One of the most abundant sources of biogas in the country is from livestock waste. According to the study conducted by the Ministry of Agriculture, Livestock and Food Supply [13], meat production will have an increase, of $34.9 \%$, from 26.5 million tons produced in 2013 to 35.8 million in 2023. This increase will be $46.4 \%$ related to chicken meat.

In this scenario, it is important to examine the way rural properties use the biogas generated by the animals and how they manage the effluents treatment. This study was conducted in the region of Foz do Iguacu, south Brazil, and it concluded that, for lack of resources or even lack of environmental awareness, most properties perform this treatment in a rudimentary way, and wasting the opportunity to use the biomass as a new income resource.

In contrast, it was noticed that some properties are already trying to change the environmental scenario in which the pigs are inserted, demonstrating that it is possible to implement actions that combine livestock with environmental conservation. An example is the Biomethane Mobility Project developed in a poultry farm that is converting wastes into vehicular renewable fuel.

\subsection{Biomethane: a vehicular renewable fuel with poultry and cattle wastes}

In recent years, Itaipu Binational has developed some projects in order to diversify its energy production from hydropower into other renewable sources such as biogas. With the technical support and expertise of the International Center of Renewable Energy - Biogás, and in partnership with Haacke Farm and Scania Brazil, this project is converting animal wastes into biomethane, as vehicular energy. The objective is to demonstrate the feasibility of biomethane application in urban mobility, so it can be integrated into the Brazilian fuel matrix and into other countries that are interested.

The farm has a herd of 80,000 laying hens and 750 cattle producing a total of 1,000 cubic meters of biogas per day as a result of the manure generated. The biogas generated from the anaerobic treatment of residual biomass into digesters is a gaseous fuel with high-energy potential; however, it is a raw material, not a product. To get to the real and qualified biogas fuel potential, it is necessary to refine it in different intensities to obtain the biomethane, which was considered a fuel product whose potential can match the one from natural gas.

For this purpose, a refinery was installed in the property to perform the removal or reduction of compounds such as hydrogen sulfide $(\mathrm{H} 2 \mathrm{~S})$, carbon dioxide $(\mathrm{CO} 2)$ and water vapor, promoting the increase of the calorific value and raising the concentration of methane on the biogas.

With the refining, biogas is converted into biomethane $98 \%$ and achieves the characteristics of natural gas, being able to meet the regulations of the National Agency of Petroleum, Natural Gas and Biofuels (ANP) No. 16/2008 and No. 08, published on January 30, 2015.

After refining, the bio-methane is compressed into cylinders for transportation, which are carried out in two interconnected cylinders baskets with $280 \mathrm{~m}^{3}$ capacity each. For the supply of biomethane, Itaipu installed one dispenser, which aims to transfer in a safe and controlled way the biomethane contained in the baskets to the vehicles. It has built a gas station supply inside the Itaipu area, as shown in Figure 3. 


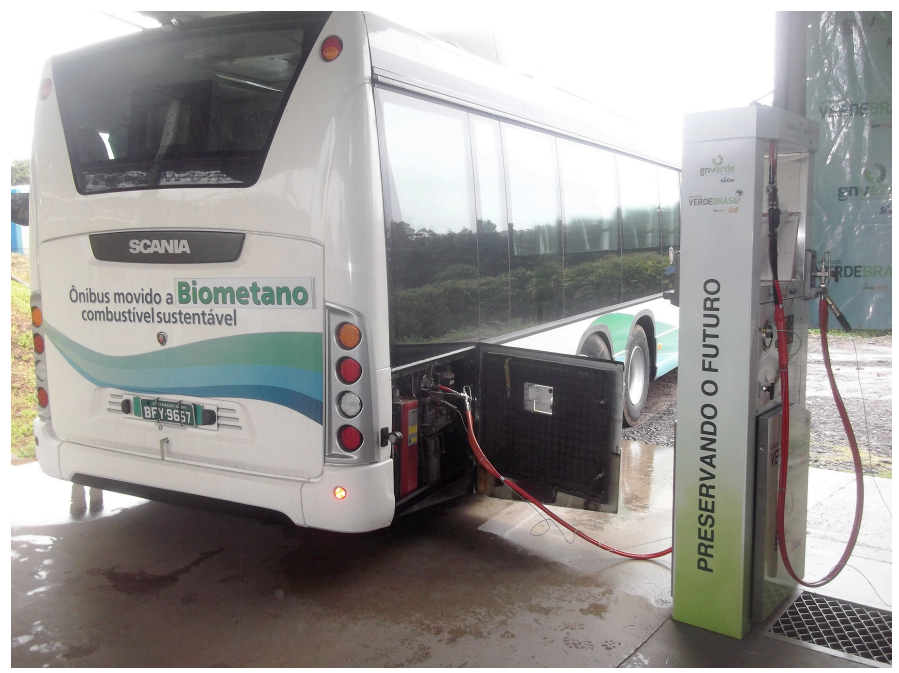

Fig. 3: Biomethane gas station

Source: International Center of Renewable Energy - Biogas, 2015 .

The biomethane fuels a Scania bus, used to transport employees and visitors in Itaipu Binational and the results obtained during the experimental period were very satisfactory.

\section{Results}

The bus model used in the project is a Scania Euro 6, one of the most modern in the world for urban mobility, manufactured in Sweden. The 15 meters long bus, with capacity for 120 passengers, has important devices that help monitor fuel quality and was originally designed to run on Compressed Natural Gas (CNG).

In 19 days of monitored tests, Scania Euro 6, carried 3,250 passengers in Itaipu complex, ran $3,000 \mathrm{~km}$ and consumed $745.58 \mathrm{~m}^{3}$ of biomethane. The average yield was 1.90 $\mathrm{km} / \mathrm{m}^{3}$, being equivalent to the consumption of $\mathrm{CNG}$ and $40 \%$ more efficient than diesel. In addition, avoid the emission of 100 tons of $\mathrm{CO} 2$ equivalent, a $70 \%$ reduction if compared to a diesel-powered bus. Furthermore, the biomethane cost per kilometer is $56 \%$ lower than the diesel cost, proving its liability.

This project demonstrates that, in addition to the essential characteristics to be considered, vehicles using biomethane can modify the national energetic matrix in a positive way, removing environmental liabilities that highly pollute water resources and air, converting them into energy assets to rural and urban mobility and providing best quality of life to people who live in these areas. Furthermore, it demonstrates that rural and urban areas are interlinked and can bring benefits if managed together.

With the results obtained in this pilot project, some municipalities are interested in support it and implement the biomethane use in their local fleet.

\section{Public policies on biogas and biomethane energies}

According to Scott and Pasqualetti [18]: "Policy initiatives are required that view energy and water in joint management terms, and that more fully unlock the potential of conservation, efficiency, and renewable energy sources. This is not simply a question of planning for optimal resource use." The authors also affirm: "Collaborative policy-making that involves public decision-makers, private initiative and a range of stakeholders will be needed to counter special-interest groups influence over infrastructure development, energy and water policy."

In this context, Stambouli et al. [19] affirm that "water and energy resources, intricately connected and increasingly scarce, are integral parts of the heritage of humanity. They require us to implement policies and strategies adapted to sustainable development".

In 2010, biogas began to be used for power generation in Brazil, being considered an energy asset, and not an environmental liability. This energy source has become subject of debate and important international agendas. Among the most important regulations that seek to give security to investors and producers of biogas can be highlighted:

a) ANEEL Normative Resolution 482/2012, which establishes the general conditions for the micro and minigeneration access to electricity power distribution systems and the power compensation system, known internationally as Net Metering. In addition, the NR aims to reduce the barriers for small-distributed generation installation, connected in voltage distribution;

b) Technical Note 13/2014 of the Energy Research Company (EPE), which was published in August 2014, with the Energy Demand Research Series 2050, and introduced biogas and biomethane in the scenario of the National Energy Planning. This study considers the current energy demand is limited due to loss of investment capacity of large generating projects, which increases the prospect of greater involvement of decentralized energy;

c) In January 2015, the National Petroleum, Natural Gas and Biofuels (ANP) published the Resolution n. 8, regulating the use of biomethane in Brazil. Biogas is considered a raw fuel, while biomethane is obtained by biogas purification and is considered a higher-value fuel. According to this resolution, the biomethane produced from waste and livestock products (such as pig manure and poultry), agricultural and agro-industrial happens to be treated in a manner similar to natural gas. This means that biomethane can have the same use of natural gas, including the same economic valuation, provided that it meets the quality requirements of the product set out in that resolution.

These regulations represented a significant advance in the scenario of renewable energy in Brazil, positioning the biogas as an effectively important fuel in the Brazilian energy matrix. 


\section{Conclusion}

Taking into account the global projections that indicate demand for freshwater, energy and food will all increase significantly over the next decades because of the population and economic growth, all countries face serious challenges in balancing economic, environmental and social challenges.

In this context, the water-energy-food nexus is critically important on international agendas with the 2015 ushering in of the Sustainable Development Goals. Considering Brazil's biogas scenario presented in this article, it has been shown that this renewable source of energy offers the possibility of aligning sustainable economic growth, livestock production, and the mitigation of carbon emissions that contribute to climate change.

Moreover, standard analysis of the economic feasibility of on-farm biogas energy production shows that a combination of rural and urban areas produces direct financial benefits to farmers and, more broadly, the provision of ecosystems services to society.

The findings indicate that livestock production can be developed on a sustainable basis, i.e., in a manner that is economically viable, socially responsible and environmentally sound.

\section{Acknowledgement}

International Center of Renewable Energies - Biogas and International Center of Hidroinformatics for the data availability, Pontifical Catholic University of Paraná and Coordination for the Improvement of Higher Education Personnel (CAPES) for the financial support and the University of Arizona for collaboration and technical support via the Inter-American Institute for Global Change Research CRN3056 project "Innovative Science and Influential Policy Dialogues for Water Security in the Arid Americas" supported by NSF Grant No. GEO-1128040 as well as the International Water Security Network supported by the Lloyd's Register Foundation.

\section{References}

[1] LANTZ, M.; SVENSSON, M.; BJORNSSON, L.; BORJESSON, P. The prospects for an expansion of biogas systems in Sweden-Incentives, barriers and potentials. Energy Policy, Vol. 35, pp. 1830-1843, 2007.

[2] PATTERSON, T.; ESTEVES, S.; DINSDALE, R.; GUWY, A. An evaluation of the policy and technoeconomic factors affecting the potential for biogas upgrading for transport fuel use in the UK. Energy Policy, Vol. 39, pp. 1806-1816, 2011.

[3] COWLEY, I.D.; WASE, D.A. Anaerobic digestion of farm waste: a review. Process Biochemistry, Vol. 16, No. 5, pp. 28-33, 1981.

[4] Kurchania, A. K, "Chapter 2- Biomass Energy", in C. Baskar et al. (eds.) Biomass Conrsion, 2012, XXVIII, pp. 91 - 122. Available in 9783642284175-c2.pdf. Accessed in August 2015.

[5] PARANA, Numbers of livestock in Parana. Available in

http://www.agricultura.pr.gov.br/arquivos/File/deral/nppr .pdf. Accessed in July 2015.

[6] International Energy Agency, 2012. Annual Report. Available

in

https://www.iea.org/publications/freepublications/publica tion/IEA_Annual_Report_publicversion.pdf Accessed in July, 2015.

[7] Scott, C. A; Kurian, M; Wescoat Jr., J.L. Chapter 2 The Water-Energy-Food Nexus: Enhancing Adaptive Capacity to Complex Global Challenges. In. M. Kurian and R. Ardakanian (eds.), Governing the Nexus, Springer International Publishing Switzerland, 2015.

[8] Hoff, H. (2011). Understanding the Nexus. Background Paper for the Bonn2011 Conference: The Water, Energy and Food Security Nexus. Stockholm Environment Institute, Stockholm.

[9] FAO. 2011. The state of the world's land and water resources for food and agriculture (SOLAW) - Managing systems at risk. Rome: Food and Agriculture Organization of the United Nations and London, Earthscan.

[10] FAO. 2011b. Energy-smart food for people and climate. Issue Paper. Rome: Food and Agriculture Organization of the United Nations.

[11] P.D. Lusk, "Methane Recovery from Animal Manures: The Current Opportunities Casebook", National Renewable Energy Laboratory US Department of Energy, 1998, Washington, DC.

[12] YIRIDOE, E. K.; GORDON, R.; BROWN, B.B. Nonmarket cobenefits and economic feasibility of onfarm biogas energy production. Energy Policy, Vol. 37, pp. 1170-1179, 2009.

[13] BRAZIL, Ministry of Agriculture, Livestock and Food Supply. Agribusiness projections: Brazil 2012/2013 to 2022/2023. Brasília: Mapa/ACS, 2013. 96 p.

[14] BRAZIL, National Water Agency, 2013. Conjuncture of Water Resources in Brazil. Available in http://arquivos.ana.gov.br/institucional/spr/conjuntura/A NA_Conjuntura_Recursos_Hidricos_Brasil/ANA_Conju ntura_Recursos_Hidricos_Brasil_2013_Final.pdf Acessed in July, 205.

[15] Brazil Energy Research Company. National Energy Balance 2015 - Base year 2014. Available in https://ben.epe.gov.br Accessed in August, 2015.

[16] LARSON, E.; KARTHA, S. Expanding roles for modernized biomass energy. Journal Energy for

Sustainable Development, Vol. 4, pp. 52, 2000. [17] BRAZIL. National Agency of Petroleum, Natural Gas and Biofuels. Vehicular energy matrix. Available in http://pt.slideshare.net/ANPgovbr/slide-ix-seminrio-deavaliao-do-mercado-de-derivados-de-petrleo-ebiocombustveis Accessed in September 2015.

[18] SCOTT, C. A., PASQUALETTI, M. J. 2010. Energy and water resources scarcity: Critical infrastructure for 
growth and economic development in Arizona and Sonora. Natural Resources Journal 50(3): 645-682.

[19] Stambouli, A.B.; Z. Khiat; S. Flazi; H. Tanemoto; M. Nakajima; H. Isoda; F. Yokoyama; S.Hannachi; K. Kurokawa; M. Shimizu; H. Koinuma. Trends and Challenges of Sustainable Energy and Water Research in North Africa: Sahara Solar Breeder Concerns at the Intersection of Energy/Water. In. International Conference on Renewable Energies and Power Quality (ICREPQ'14),
Cordoba
(Spain).
Available

in

http://www.icrepq.com/icrepq'14/204.14-Stambouli.pdf

Accessed in August, 2015. 